\title{
METODE DAN STRATEGI PENGAJARAN MEMBACA PADA PEMBELAJARAN BAHASA ARAB BAGI PEMULA
}

\author{
Sitti Aisyah Chalik ${ }^{1}$ \\ ${ }^{1}$ Universitas Islam Negeri Alauddin Makassar \\ E-mail : sittiaisyahchalik@gmail.com
}

Doi: $10.24252 /$ saa.v8i1.15031

\begin{abstract}
This paper discusses the methods and strategies of reading in Arabic lessons. As is well known that language skills include four aspects, namely speaking skills, writing skills, reading skills, and listening skills. At the beginner level, reading is a basic skill that must be mastered by everyone who wants to learn Arabic as a foreign language and as is well known that Arabic is a Foreign Language for non-Arabs. Teaching Arabic which is a foreign language requires various methods and strategies appropriate so that learning objectives can be achieved effectively and efficiently.
\end{abstract}

Keywords: Method; Strategy; Reading

\section{PENDAHULUAN}

Bahasa Arab merupakan bahasa yang paling utama di dalam tradisi dunia Islam. Oleh karena itu, dibutuhkan kemampuan berbahasa Arab untuk mengetahui pesan-pesan yang terkandung di dalam alquran dan hadis yang merupakan sumber pokok ajaran Islam. Dengan demikian, bahasa Arab merupakan hal penting yang harus dipelajari.

Pembelajaran adalah sebuah sistem, yaitu terdiri dari berbagai unsur dan komponen yang saling terkait dan saling memengaruhi. Sistem adalah totalitas dari semua unsur yang saling terkait. ${ }^{1}$ Untuk pembelajaran bahasa diperlukan sebuah upaya yang berbeda dengan pembelajaran materi lainnya. Dalam konteks ini, pendidikan dalam materi bahasa asing perlu dilihat dalam sistem pendidikan secara keseluruhan ${ }^{2}$.

Di dalam proses pembelajaran, pendidik harus memilih metode yang sesuai dengan karakteristik peserta didik. Di samping itu, mengajarkan pelajaran bahasa Arab memerlukan strategi untuk menyempurnakan metode yang dipilih. Strategi pembelajaran dilakukan agar peserta didik dapat menerima materi pelajaran lebih efektif dan efisien.

Sebagaimana telah diketahui bahwa keterampilan berbahasa ada empat, yaitu menyimak (istima'), berbicara (kalam), membaca (qira'ah), dan menulis (kitabah) ${ }^{3}{ }^{3}$ Keterampilan membaca merupakan keterampilan utama yang harus diajarkan dalam pengajaran bahasa pada tingkat pemula. Untuk melatih keterampilan membaca, dibutuhkan beberapa metode. Metode-metode tersebut memiliki kelebihan dan kekurangannya masing-masing. Di dalam tulisan ini, akan dijelaskan secara ringkas mengenai metode dan strategi pengajaran membaca pada pelajaran bahasa Arab bagi pemula.

\footnotetext{
${ }^{1}$ Munir, Perencanaan Sistem Pengajaran Bahasa Arab, (Cet. I; Jakarta: Kencana, 2016), h.5

${ }^{2}$ Ismail Suardi Wekke, Pembelajaran Bahasa Arab di Madrasah, (Cet. I; Yogyakarta: Deepublish, 2018), h. $21-22$

${ }^{3}$ Ahmad Muradi, Pembelajaran Menulis Bahasa Arab dalam Perspektif Komunikatif, (Cet. II; Jakarta: Kencana, 2016), h. 17
} 
Agar pembahasan ini lebih sistematis, maka disusun rumusan masalah sebagai berikut;

1. Apa pengertian metode dan strategi pembelajaran?

2. Apa komponen strategi pembelajaran?

3. Bagaimana metodologi dan strategi pengajaran membaca pada pembelajaran bahasa Arab bagi pemula?

\section{METODE}

Jenis penelitian pada tulisan ini menggunakan jenis penelitian library research atau studi kepustakaan. Sedangkan tekhnik pengumpulan datanya dilakukan dengan mengkaji dan menganalisa berbagai teks-teks dari berbagai referensi kemudian dikumpulkan. Metode pengolahan data dalam tulisan ini dilakukan dengan mengumpulkan berbagai referensi yang memiliki materi yang berkaitan dengan pembahasan yang akan dikaji. Tekhnik analisa yang digunakan pada tulisan ini yaitu metode normatif yang mencari kejelasan mengenai metode dan strategi pengajaran membaca pada pembelajaran bahasa Arab.

\section{HASIL PENELITIAN DAN PEMBAHASAN}

\section{Pengertian Metode dan Strategi Pembelajaran}

\section{Pengertian Metode Pembelajaran}

Secara etimologi, istilah metodologi berasal dari bahasa Yunani yaitu metodos yang berarti cara atau jalan, dan logos yang berarti ilmu. Sedangkan secara terminologi, metodologi berarti ilmu pengetahuan yang mempelajari tentang cara-cara atau jalan yang ditempuh untuk mencapai suatu tujuan dengan hasil yang efektif dan efisien. Metodologi pembelajaran bahasa Arab adalah cara atau jalan yang ditempuh untuk menyajikan bahanbahan pelajaran bahasa Arab agar mudah diterima, diserap dan dikuasai anak didik dengan baik dan menyenangkan ${ }^{4}$.

Metode ialah suatu cara kerja yang sistematik dan umum, terutama dalam mencari kebenaran ilmiah. Dalam kaitannya dengan pembelajaran bahasa Arab maka pembahasan metode akan selalu bertolak dari hakikat usaha menyampaikan bahan pelajaran kepada peserta didik agar pelajaran itu diterima. Di dalam tangan siapa metode itu tergenggam, maka kepadanya ditunt ut suatu keampuan dan keterampilan menggunakannya.

Variasi metode pembelajaran akan membantu siswa untuk secara aktif dapat menggunakan sel-sel otak mereka untuk turut serta memecahkan persoalan, menemukan ide pokok dari suatu materi perkuliahan, dan tentu saja secara aktif akan mendominasi aktifitas pembelajaran. Dengan cara ini, terciptalah suasana yang lebih menyenangkan dan membisakan karena hasil belajar dapat dimaksimalkan.

\section{Pengertian Strategi Pembelajaran}

Strategi berasal dari bahasa Yunani yaitu strategos yang artinya suatu usaha untuk mencapai suatu kemenangan dalam suatu peperangan awalnya digunakan dalam lingkungan militer namun istilah strategi digunakan dalam berbagai bidang yang memiliki esensi yang relatif sama termasuk diadopsi dalam konteks pembelajaran yang dikenal dalam istilah

\footnotetext{
${ }^{4}$ Ahmad Izzan, Metodologi Pembelajaran Bahasa Arab, (Bandung: Humaniora, 2009), h.

72
} 
strategi pembelajaran ${ }^{5}$.

Pendapat dari Moedjiono strategi pembelajaran adalah kegiatan guru untuk memikirkan dan mengupayakan terjadinya konsisiten antara aspek-aspek dari komponen pembentuk sistem pembelajaran, dimana untuk itu guru menggunakan siasat tertent $u^{6}$.

Secara umum strategi mempunyai pengertian suatu garis-garis besar haluan untuk bertindak dalam usaha mencapai sasaran yang telah dilakukan. Dihubungkan dengan belajar mengajar, strategi bisa diartikan sebagai pola-pola umum kegiatan guru dan anak didik dalam perwujudan kegiatan belajar mengajar untuk mencapai tujuan yang telah digariskan ${ }^{7}$.

Strategi pembelajaran adalah rencana, cara-cara, serta sarana yang akan digunakan dalam sebuah kegiatan belajar mengajar mulai pembukaan hingga penutup dengan memperhatikan situasi dan kondisi, sumber belajar, kebutuhan peserta didik dan karakteristik peserta didik yang dihadapi untuk mencapai tujuan pembelajaran yang telah ditetapkan ${ }^{8}$.

Merujuk dari beberapa pendapat di atas, penulis menarik kesimpulan bahwa strategi pembelajaran adalah sebuah proses yang berisi cara-cara atau siasat yang telah direncanakan untuk memudahkan proses pencapaian tujuan pembelajaran yang telah ditetapkan dengan memperhatikan situasi dan kondisi.

Sukses tidaknya suatu program pengajaran bahasa senantiasa dinilai dari strategi bahasa yang digunakan, karena strategilah yang menentukan tercapainya isi dan cara mengajarkan bahasa. Di lain pihak, ada pendapat ekstrim yang menyatakan bahwa strategi itu tidak penting. Yang penting adalah kemauan belajar dan kualitas mahasiswa. Ada pula yang berpendapat bahwa strategi itu hanya sekedar alat saja, dosenlah yang paling menentukan. Terlepas dari masalah setuju atau tidak setuju dengan beberapa pendapat di atas, adalah suatu kenyataan bahwa setiap saat para dosen dihadapkan dengan strategi baru.

Penulis menarik kesimpulan bahwa strategi adalah rancangan serangkaian kegiatan untuk mencapai tujuan tertentu; sedangkan metode adalah cara yang digunakan untuk mengimplementasikan strategi. Dengan demikian stretegi dan metode itu tidak bisa dipisahkan. Strategi dan metode pembelajaran harus dirancang sesuai dengan tujuan yang ingin dicapai.

Setiap metode mempunyai kelebihan dan kelemahannya. Oleh karena itu, guru harus dapat memilih metode yang tepat, yakni yang sesuai dengan materi, siswa, situasi, dan tujuan yang akan dicapai. Guru dapat memilih berbagai metode agar adanya variasi dalam mengajar. Penggunaan metode yang bervariasi dapat mencegah terjadinya kebosanan pada diri siswa, dengan penggunaan metode yang bervariasi akan menjadikan kegiatan pembelajaran lebih bergairah serta menciptakan suasana yang kondusif di dalam kelas ${ }^{9}$.

Komponen Strategi Pembelajaran

Mustofa (2011: 10-11) mengungkapkan bahwasannya strategi pembelajaran meliputi lima komponen, yaitu: (1) kegiatan pembelajaran pendahuluan, (2) penyampaian informasi, (3) partisipasi peserta didik, (4) evaluasi, dan (5) kegiatan lanjutan atau follow up ${ }^{10}$.

\footnotetext{
${ }^{5}$ Masitoh, cs, Strategi Pembelajaran (Jakarta: DEPAG RI, 2009), h. 37

${ }^{6}$ Masitoh, cs, Strategi Pembelajaran, h. 38.

${ }^{7}$ Moh. Suardi, Belajar dan Pembelajaran, (Cet. I; Yogyakarta: Deepublish, 2018), h. 29

${ }^{8}$ Hasna Qonita Khanza, "Strategi Pembelajaran Bahasa Arab”, Prosiding Konferensi Nasional Bahasa Arab II, (2016): h. 54

${ }^{9}$ Saifuddin Mahmud, cs, Strategi Belajar Mengajar, (Cet. I; tt: Syiah Kuala, 2017), h. 15

${ }^{10}$ Hasna Qonita Khanza, "Strategi Pembelajaran Bahasa Arab", h. 54-56
} 
a. Kegiatan Pembelajaran Pendahuluan

Kegiatan pembelajaran pendahuluan merupakan cara dan upaya guru yang dipilih dalam menjelaskan tujuan pembelajaran dan melakukan apersepsi. Pada kegiatan pendahuluan ini guru diharapkan dapat menarik minat peserta didik atas materi yang akan disampaikan dalam kurun waktu tertentu, pada bagian ini memegang peranan penting karena menjelaskan proses pembelajaran secara keseluruhan.

Kegiatan pendahuluan dapat dilakukan dengan beberapa teknik, diantaranya menjelaskan tujuan pembelajaran khusus yang akan dicapai oleh peserta didik dan apersepsi untuk membangunkan pengetahuan lama peserta didik serta dikaitkan dengan pengetahuan baru yang akan dipelajari.

b. Penyampaian Informasi

Kegiatan ini dilakukan di dalam ruang kelas atau di luar kelas dalam rangkaian proses belajar mengajar. Dalam penyampaian informasi ini dibutuhkan keahlian seorang guru untuk meramunya menjadi sebuah kegiatan yang menarik dan menyenangkan, agar dalam mentransfer ilmu pengetahuan tercipta situasi yang kondusif. Hal tersebut dapat meningkatkan motivasi belajar peserta didik.

Hal yang harus diperhatikan saat melakukan kegiatan penyampaian informasi adalah (a) urutan penyampaian materi harus berurutan, misalnya dari teori ke praktik atau sebaliknya, dimulai dari yang mudah ke yang lebih sulit, serta dari hal yang bersifat konkret ke hal yang bersifat abstrak, (b) ruang lingkup materi tergantung pada karakteristik peserta didik dan jenis materinya yang telah tergambar pada saat penentuan tujuan pembelajaran, dan (c) materi yang disampaikan mencakup materi dalam bentuk pengetahuan (berupa fakta dan informasi terperinci), keterampilan (berupa langkah, prosedur, keadaan, dan syarat- syarat tertentu), dan sikap (berupa pendapat, ide, saran, tanggapan).

\section{c. Partisipasi Peserta Didik}

Proses pembelajaran saat ini peserta didik harus memiliki peran yang lebih utama. Artinya, peserta didik diharuskan lebih aktif dalam proses pembelajaran. Untuk menjadikan peserta didik tersebut aktif maka dibutuhkan rancangan strategi yang tepat. Partisipasi peserta didik dapat berbentuk praktik secara langsung atau memberikan latihan-latihan yang mengarah pada pembentukan sikap dan mental peserta didik.

\section{d. Evaluasi}

Evaluasi perlu dilakukan untuk mengukur keberhasilan proses pembelajaran yang telah dilakukan, evaluasi dapat berbentuk umpan balik yang dilakukan oleh guru pada akhir proses pembelajaran yang berlangsung, atau dalam

bentuk pretest, maupun dalam bentuk memberikan soal-soal tes. Evaluasi yang diberikan bisa berupa tes lisan ataupun tes tulis.

\section{e. Kegiatan Lanjutan (follow up)}

Kegiatan lanjutan ini perlu dilakukan oleh guru agar tercipta pembelajaran berkelanjutan. Bentuk kegiatan lanjutan ini bias berupa memberikan tugas pekerjaan rumah (PR), kegiatankegiatan yang bersifat positif, tugas bersama atau tugas kelompok, dan lain sebagainya. Namun kegiatan lanjutan ini tidak boleh dipaksakan, guru harus memperhatikan kondisi fisik 
dan psikis peserta didik serta materi yang ada, agar terjadi proses pembelajaran yang kontra produktif.

Peraturan Menteri Pendidikan Nasional nomor 41 (2007: 5-6) mengungkapkan bahwa kegiatan belajar mengajar meliputi: kegiatan pendahuluan, kegiatan inti, dan kegiatan penutup ${ }^{11}$.

\section{f. Kegiatan Pendahuluan}

Pendahuluan merupakan kegiatan awal dalam suatu pertemuan pembelajaran yang ditujukan untuk membangkitkan motivasi dan memfokuskan perhatian peserta didik untuk berpartisipasi aktif dalam proses pembelajaran.

\section{g. Kegiatan Inti}

Kegiatan inti merupakan proses pembelajaran untuk mencapai kompetensi dasar yang dilakukan secara interaktif, inspiratif, menyenangkan, menantang, memotivasi peserta didik untuk aktif, dan memberikan ruang bagi kreatifitas dan kemandirian sesuai dengan bakat minat dan perkembangan fisik dan psikologis peserta didik.

Kegiatan ini dilakukan secara sistematis dan sistemik melalui proses eksplorasi, elaborasi, dan konfirmasi. Eksplorasi melibatkan peserta didik untuk mencari informasi, menggunakan berbagai pendekatan, media, dan sumber belajar lain, memfasilitasi terjadi interaksi, dan melibatkan peserta didik secara aktif. Sedangkan dalam elaborasi guru membiasakan peserta didik untuk membaca dan menulis, memfasilitasi peserta didik melalui pemberian tugas dan diskusi, memberi kesempatan berfikir, analisis dan menyelesaikan masalah dan berani,memfasilitasi dalam pembelajaran kooperatif dan kolaboratif, berkompetisi secara sehat, membuat laporan eksplorasi, melakukan pameran, turnamen dan festifal, dan memfasilitasi peserta didik melakukan kegiatan yang menumbuhkan kebanggaan dan percaya diri. Dan pada proses konfirmasi guru memberikan uman balik positif dan penguatan, memberikan konfirmasi terhadap hasil eksplorasi dan elaborasi, memfasilitasi melakukan refleksi, dan memfasilitasi peserta didik untuk memperoleh pengalaman yang bermakna.

\section{h. Kegiatan Penutup}

Penutup merupakan kegiatan yang dilakukan untuk mengakhiri aktifitas pembelajaran yang dapat dilakukan dalam bentuk rangkuman atau kesimpulan, penelitian dan refleksi, umpan balik, dan tindak lanjut.

Mager (dalam Sunhaji, 2008: 6) menyampaikan beberapa kriteria yang dapat digunakan dalam memilih strategi pembelajaran, yaitu sebagai berikut:

(1) Berorientasi pada tujuan pembelajaran. Tipe perilaku apa yang diharapkan dapat dicapai oleh peserta didik, misalnya menyusun bagan analisis pembelajaran. Hal ini berarti metode yang paling dekat dan sesuai yang dikehendaki oleh tujuan pengajaran khusus adalah latihan atau praktik langsung.

(2) Pilih teknik pembelajaran sesuai dengan keterampilan yang diharapkan dapat dimiliki saat bekerja, peserta didik dituntut untuk pandai memprogram data komputer (programmer). Hal ini berarti metode yang paling mungkin digunakan adalah praktikum dan analisis kasus atau pemecahan masalah (problem solving).

\section{Metodologi dan Strategi Pengajaran Membaca pada Pembelajaran Bahasa Arab bagi Pemula}

\footnotetext{
${ }^{11}$ Hasna Qonita Khanza, “Strategi Pembelajaran Bahasa Arab”, h. 56-57
} 
Pembelajaran qira'ah (membaca) seringkali disebut dengan pelajaran muuthala'ah (menela'ah). Keduanya memang sama-sama belajar yang berbasis bacaan. Namun demikian, kedua istilah tersebut memiliki perbedaan. Qira'ah dapat diartikan sebagai pelajaran membaca, sedangkan muthala'ah lebih menekankan pada aspek analisis dan pemahaman terhadap apa yang dibaca. Karena keduanya memiliki perbedaan penekanan, maka dalam pemilihan metode atau strategi pembelajarannya pun tentu akan terdapat perbedaan. Kedua istilah tersebut juga dapat dipahami sebagai proses, artinya bahwa ketrampilan membaca itu meliputi latihan membaca dengan benar sampai dengan taraf kemampuan memahami dan menganalisis isi bacaan.

Metode membaca dikembangkan berdasarkan asumsi bahwa pengajaran bahasa tidak bisa bersifat multi-tujuan, dan bahwa kemampuan membaca adalah tujuan yang paling realistik ditinjau dari kebutuhan pembelajar bahasa asing dan kemudahan dalam pemerolehannya. Kemahiran membaca merupakan bekal bagi pembelajar untuk mengembangkan pengetahuannya secara mandiri. Dengan demikian asumsinya bersifat pragmatis, bukan filosofis teoritis ${ }^{12}$. Karakteristik metode membaca ini antara lain adalah sebagai berikut: ${ }^{13}$

1) Tujuan utamanya adalah kemahiran membaca, yaitu agar pelajar mampu memahami teks ilmiah untuk keperluan studi mereka.

2) Materi pelajaran berupa buku bacaan utama dengan suplemen daftar kosa kata dan pertanyaan-pertanyaan isi bacaan, buku bacaan penunjang untuk perluasan, buku latihan mengarang terbimbing dan percakapan.

3) Basis kegiatan pembelajaran adalah memahami isi bacaan, didahului oleh pengenalan kosa kata pokok dan maknanya, kemudian mendiskusikan isi bacaan dengan bantuan guru. Pemahaman isi bacaan melalui proses analisis, tidak dengan penerjemahan harfiah, meskipun bahasa ibu boleh digunakan dalam mendiskusikan teks.

4) Kaidah bahasa diterangkan seperlunya tidak boleh berkepanjangan. Kelebihan dan Kekurangan dari metode ini adalah sebagai berikut: ${ }^{14}$

Kelebihan:

1) Pelajar terlatihmemahami bacaan dengananalisis, tidak melalui penerjemahan.

2) Pelajar menguasai kosa kata dengan baik.

3) Pelajar memahami penggunaan tata bahasa. Kekurangan:

1) Pelajar tidak terampil dalam menyimak dan berbicara, karena yang menjadi perhatian utama adalah keterampilan membaca.

2) Pelajar kurang terampil dalam mengarang bebas.

3) Karena kosa kata yang dikenalkan hanya yang berkaitan dengan bacaan, maka pelajar lemah dalam memahami teks yang berbeda.

Dalam bidang pengajaran membaca terdapat beberapa teori dan metode. Masingmasing metode tersebut mempunyai kelebihan dan kekurangannya masing-masing. Metodemetode tersebut antara lain: ${ }^{15}$

\footnotetext{
${ }^{12}$ Ahmad Fuad Effendy, Metodologi Pengajaran Bahasa Arab (Malang: Misykat, 2012),h.54

13 Ahmad Fuad Effendy, Metodologi Pengajaran Bahasa Arab, h. 54

${ }^{14}$ Ahmad Fuad Effendy, Metodologi Pengajaran Bahasa Arab, h. 53

${ }^{15}$ Muhammad Ali Al-Khuliy, Model Pembelajaran Bahasa Arab, (Cet. I; Bandung: Royyan Press,
} 2016), h. 75-85 


\section{a. Metode Harfiyyah}

Pada metode ini guru memulainya dengan mengajarkan huruf-huruf hijayyah satu per satu. Guru mengajarkan huruf-huruf alif, ba, ta, dan seterusnya sampai ya. Para pembelajar belajar membaca huruf apabila mereka melihat tulisannya. Setelah itu mereka belajar membaca suku kata dan selanjutnya kata. Metode ini disebut juga dengan metode Huruf, atau metode Hijayyah, atau metode Abjadiyyah, atau juga metode Alfabet.

Kelebihan metode ini adalah terasa mudah bagi guru, dikenal oleh para ibu dan bapak, dan menjadikan para pembelajar kenal dengan huruf. Akan tetapi sebagian para ahli mengkritik metode ini. Mereka berkata bahwa satu huruf terdiri dari berbagai bunyi sebagai pengganti dari satu bunyi. Huruf "w" namanya "سين / sin". Pengkritik metode ini berpendapat bahwa metode ini dapat mengakibatkan para pembelajar lambat dalam belajar membaca. Karena mereka cenderung membaca huruf per huruf bukannya membaca kata secara keseluruhan.

\section{b. Metode Shautiyyah}

Dari segi proses pentahapan huruf ke suku kata dan suku kata ke kata metode ini mempunyai kesamaan dengan metode membaca huruf. Akan tetapi ada perbedaan dengannya dari segi pengajaran huruf. Pada metode membaca huruf, huruf-huruf diberikan sesuai dengan namanya. Huruf "ص" misalnya diajarkan bahwa huruf tersebut "صاد / shad". Akan tetapi dalam metode Membaca Bunyi huruf tersebut diajarkan dengan "صن".

Kelebihan metode ini bahwa setiap huruf dipanggil sesuai dengan bunyinya. Akan tetapi seperti halnya dengan metode pertama, metode inipun mempunyai kelemahan yaitu dapat mengurangi kecepakan para pembelajar dalam mempelajari keterampilan membaca. Hal ini karena proses belajarnya diadakan melalui pembiasaan mengeja. Demikian pendapat para pengkritik metode ini.

\section{c. Metode Maqthaiyyah}

Metode ini mengajarkan membaca pada pembelajar dengan cara mengajarkan suku kata terlebih dahulu. Kemudian setelah itu mereka diajarkan membaca kata-kata yang terdiri dari suku kata. Untuk mengajarkan suku kata terlebih dahulu dikenalkan kepada mereka huruf-huruf madd. Pertama kali mereka diajarkan " "J،", kemudian mereka belajar membaca

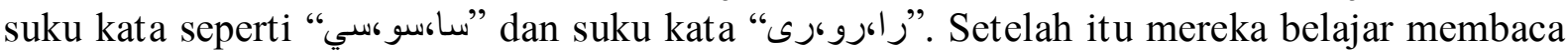

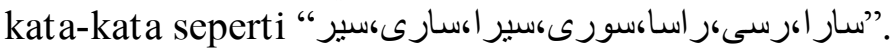

Metode ini kadang-kadang lebih baik daripada metode Harfiyyah atau Shautiyyah. Karena metode ini memulai pengajarannya dari satuan yang lebih besar dari huruf atau bunyi. Ketiga metode ini (Metode Harfiyyah, Metode Shautiyyah, dan Maqthaiyyah) disebut dengan metode Juziyyah atau Tarkibiyyah. Karena dimula dari juz (bagian) yang kemudian berpindah ke suku kata dan kata.

Selain ketiga metode di atas ada beberapa metode yang berlawanan arahnya dengan ketiga metode tersebut, yaitu metode Kuliyyah atau metode Tahliliyyah. Dinamakan metode kuliyyah karena metode tersebut dimulai dari umum ke khusus. Di antara yang termasuk ke dalam metode ini adalah metode Kata dan metode Kalimat.

\section{d. Metode Kata}

Metode ini merupakan salah satu dari metode Kuliyyah, karena para pembelajar mulai belajar membaca dari kalimat kemudian mereka belajar huruf- huruf yang menyusun katakata tersebut. Metode ini bertolak belakang sama sekali dengan metode Harfiyyah dan metode Sautiyyah yang mengajarkan huruf atau bunyi pertama kali dan kemudian pindah ke 
membaca suku kata dan kata

Metode ini mempunyai kelebihan yaitu metode ini memulai langkahnya dengan membaca satuan bunyi yang mempunyai makna. Hal ini berbeda dengan metode-metode juziyyah yang memulainya dari satuan bunyi yang tidak mempunyai makna, sperti huruf, bunyi, dan suku kata. Metode inipun memiliki kelemahan yaitu metode ini kadang-kadang dapat melemahkan kemampuan menulis para pembelajar. Hal ini karena perhatian para pembelajar pada huruf- huruf kurang sempurna.

\section{e. Metode Kalimat}

Metode kalimat ini dilakukan dengan menyajikan kalimat pendek pada kartu atau papan tulis. Kemudian guru membacanya yang kemudian diulang oleh pembelajar dengan beberapa kali. Setelah itu guru menambah sebuah kata baru dengan diucapkan langsung. Para pembelajar mengikuti apa yang diucapkan guru mereka. Seperti ذهب الولد-ذهب الولد مسرعا. Setelah itu kedua kalimat tersebut diperbandingkan. Hal ini untuk mengetahui kata-kata yang sama dan yang berbeda di antara kedua kalimat tersebut. Setelah itu guru menganalisis kata-kata sampai ke huruf-hurufnya. Demikianlah, metode ini berjalan dari kalimat ke kata, dan dari kata ke huruf. Metode ini merupakan salah satu dari metode Kulliyyah atau Tahliliyyah.

Kelebihan metode ini yaitu para pembelajar terbiasa membaca unit-unit terbesar dan semaksimal mungkin menggunakan kemampuan penglihatan. Hal ini dapat mempercepat kemampuan membaca mereka. Walaupun demikian, metode ini pun mempunyai beberapa kelemahan. Kelemahan utama metode ini adalah memerlukan usaha yang maksimal. Guru yang mahir dan berpengalaman sangat dituntut pada metode ini, namun kenyataannya jarang ditemukan.

\section{f. Metode Integratif}

Para pendukung metode ini berpendapat bahwa tiap-tiap metode mempunyai kelebihan dan kekurangannya sendiri-sendiri. Oleh karena itu jalan terbaiknya adalah dengan mengambil aspek-aspek positif dari metode-metode tersebut dan menjauhkan dari aspekaspek negatifnya, yaitu dengan jalan tidak hanya berpegang pada satu metode saja dengan tidak menghiraukan metode- metode lainnya. Metode integratif meliputi

1. Qiraah Mukatstsafah (Membaca Intensif)

Qiraah Mukatstsafah adalah qiraah yang digunakan sebgai media untuk pengajaran kata-kata baru dan struktur-struktur baru. Oleh karena itu materinya lebih tinggi daripada tingkat pembelajar. Materi ini terbentuk sebagai tulang punggung dalam program pengajaran bahasa.

2. Qiraah Takmiliyah (Suplemen)

Jenis membaca ini dinamakan dengan Qiraah Takmiliyah karena berfungsi sebagai penyempurnya dari peran Qiraah Mukatstsafah. Jenis ini juga dinamakan dengan Qiraah Muwassa'ah. Qiraah Takmiliyah biasanya digunakan untuk membaca ceritacerita panjang dan pendek. Tujuan utama dari jenis membaca ini adalah untuk kesenangan para pembelajar serta memantapkan apa yang mereka pelajari berupa kata-kata dan strukur-struktur pada Qiraah Mukatstsafah.

3. Qiraah Shamitah (Membaca dalam Hati)

Membaca dalam hati dapat dilakukan dengan sempurna tanpa suara, desauan, dan gerakan lidah. Bahkan dalam membaca dalam hati tidak ada getaran pita suara pada pangkal tenggorokan pembaca. Ini berarti bahwa makna pada kata-kata yang tertulis berpindah langsung kepada ingatan pembaca tanpa melalui tahapan bunyi. Tujuan 
utama dari kegiatan membaca dalam hati adalah pemahaman. Pemahaman merupakan tujuan utama dari kegiatan membaca bagi manusia. Sedangkan membaca keras hanya sedikit saja diperlukan dan dilakukan oleh manusia, seperti untuk siaran berita dan pengumuman yang memang memerlukan bacaan keras.

4. Qiraah Jahriyyah (Membaca Nyaring)

Ketika seorang guru meminta para pembelajar membaca teks dengan nyaring, maka tujuan utama dari kegiatan tersebut adalah untuk melatih para pembelajar dalam menghadapi suasana tatap muka, seperti: membaca berita, mengajar, kuliah umum, dan membaca di radio atau televisi.

\section{KESIMPULAN}

Strategi pembelajaran adalah sebuah proses yang berisi cara-cara atau siasat yang telah direncanakan untuk memudahkan proses pencapaian tujuan pembelajaran yang telah ditetapkan dengan memperhatikan situasi dan kondisi. strategi pembelajaran adalah sebuah proses yang berisi cara-cara atau siasat yang telah direncanakan untuk memudahkan proses pencapaian tujuan pembelajaran yang telah ditetapkan dengan memperhatikan situasi dan kondisi. Strategi pembelajaran meliputi lima komponen, yaitu: (1) kegiatan pembelajaran pendahuluan, (2) penyampaian informasi, (3) partisipasi peserta didik, (4) evaluasi, dan (5) kegiatan lanjutan atau follow up. Dalam bidang pengajaran membaca terdapat beberapa teori dan metode. Masing-masing metode tersebut mempunyai kelebihan dan kekurangannya masing-masing. Metode-metode tersebut antara lain: (1) metode harfiyyah, (2) metode shautiyyah, (3) metode maqthaiyyah, (4) metode kata, (5) metode kalimat, (6) metode integratif. Metode integratif meliputi qiraah mukatstsaffah, qiraah takmiliyyah, qiraah shamitah, dan qiraah jahriyyah.

\section{IMPLIKASI}

Mengetahui pengertian, komponen, dan metodologi dalam pengajaran membaca pada pembelajaran bahasa Arab bagi pemula akan membuka cakrawala berfikir tentang berbagai metode-metode yang ada dalam mengajarkan membaca bahasa arab senagai bahasa asing bagi pembelajar

\section{DAFTAR PUSTAKA}

Al-Khuliy. 2016. Model Pembelajaran Bahasa Arab. Bandung: Royyan Press Effendy, Ahmad Fuad. 2012. Metodologi Pengajaran Bahasa Arab. Malang: Misykat Izzan, Ahmad. 2009. Metodologi Pembelajaran Bahasa Arab. Bandung: Humaniora

Khanza, Hasna Qonita. 2016. Strategi Pembelajaran Bahasa Arab. Prosiding Konferensi Nasional Bahasa Arab II

Mahmud, Saifuddin, cs. 2017. Strategi Belajar Mengajar. Syiah Kuala

Masitoh, cs, .2009. Strategi Pembelajaran. Jakarta: DEPAG RI

Munir. 2016. Perencanaan Sistem Pengajaran Bahasa Arab. Jakarta: Kencana

Muradi, Ahmad. 2016. Pembelajaran Menulis Bahasa Arab dalam Perspektif Komunikatif. Jakarta: Kencana

Suardi, Moh. 2018. Belajar dan Pembelajaran. Yogyakarta: Deepublish

Wekke, Ismail Suardi. 2018. Pembelajaran Bahasa Arab di Madrasah. Yogyakarta: Deepublish 